\title{
CONTRACTING WITH THE STATE WITHOUT MEETING CIVIL SERVICE REQUIREMENTS
}

On November 6, 1956, the California electorate defeated Proposition 10,1 an amendment to the civil service provision of the California constitution. ${ }^{2}$ The amendment was intended to liberalize existing restrictions on the authority of state agencies to contract for their engineering and architectural work outside of civil service. The efficacy of both the present system and the proposed amendment was questioned. Charges ranged from complaints as to the capacity of the civil service structure to handle the imcreasing volume of state work ${ }^{3}$ to the assertion, on the other side, that the proposed amendment was an attempt to return to the spoils system. From a legal point of view the most serious of these charges was that the present law does not allow state agencies to contract with independent contractors when it is clearly in the interest of the public to do so..$^{5}$ If we assune that "interest of the public" means when the civil service structure cannot handle a job, an analysis of the law proves this not to be the case.

\section{Civil Service in the California Constitution}

Article XXIV of the California constitution was adopted in 1934. Its purposes were said to be: ${ }^{\circ}$

(1) Employment in the classified service based ... on merit; (2) a non-partisan Personnel Board; (3) prohibition against exemptions from the merit system of employment; (4) correction of the temporary political appointment evil.

Section 1 provides for permanent appointments and promotions to be made exclusively upon a general merit system based on comparative competitive examinations. Permanent appoimtment apparently means any appointment to last longer than nime months in any consecutive twelve months. ${ }^{7}$ Section 2 sets up a

1 Senate Constitutional Amendment No. 6 (Proposition 10), an amendment that would have added $\S 8$ to article XXIV of the California constitution, read: "Nothing in this article shall prevent the Legislature from enacting legislation to authorize the employment of private architects and engineers on a contract basis for the performance of work which the obtainable staff of a state agency is unable to perform within the time the public interest requires such work to be done." The proposition was badly worded, for it did not specify what "engineer," "public interest," and "obtainable staff" meant. Further, it would lave removed the check of the State Personnel Board from these activities.

2 The California civil service is based on Car. Const. art. XXIV and Car. Govr. Code $8 \$ 18500-9763$.

${ }^{3}$ Voluminous material was put out by both sides in pamphlets and newspapers. The principal proponent was the California Council of Architects.

1 Principal opponents were the League of Women Voters and the California State Employees Association.

5 In the Voters Handbook it was said in favor of Proposition 10: "Under the present provisions of the Constitution it is not certain whether a state agency may employ architects or engineers under contract rather than as state employees . . . when it is in the pubhic interest to do so." Joln F. McCarthy (State Senator), Proposed Amendments to the Constitution (Voters Handbook) Part 1, p. 15 (1956).

( State Compensation Ins. Fund v. Riley, 9 Cal. 2d 126, 134, 69 P.2d 985 (1937); accord, Almassy v. Los Angeles County Civil Service Comm'n, 34 Cal. 2d 387, 210 P.2d 503 (1949); Allen v. McKinley, 18 Cal. 2d 697, 117 P.2d 342 (1941); Stockburger v. Riley, 21 Cal. App. 2d $165,170,68$ P.2d 741 (1937); Cax. Govt. Code $\$ 18500$.

7 CAL. Const. art. XXIV, \& 6. 
State Personnel Board, consisting of an executive officer, ${ }^{8}$ and five members appointed by the Governor with the advice and consent of the Senate. ${ }^{\circ}$ Section 3 defines the powers of the Board, mostly by reference to enactments of the Legislature both previous ${ }^{10}$ and subsequent ${ }^{11}$ to the passage of article XXIV.

- The scope of application of the civil service is described in section $4(a):^{12}$

The provisions hereof shall apply to, and the term 'state civil service' shall include, every officer and employee of this state except .....

The specific exceptions include all state officers elected by the people, employees of the Governor's office, persons employed by the University of California, and others of similar nature. ${ }^{13} \mathrm{~A}$ literal reading of this section would seem to admit of no exceptions other than those specified; 14 however, the courts have stated that this is not the case.

\section{The Courts and Article XXIV}

The California Supreme Court has declared that the provisions of article XXIV are comprehensive, ${ }^{15}$ include professional as well as non-professional service, ${ }^{10}$ and independent contractors as well as "employees" in the master-servant usage of the word. ${ }^{17}$ The inclusion of independent contractors is of vital importance as it cuts off a wide area of possible subversion of the civil service system.

However, despite these statements, these same cases show areas of exception. The question of the scope of article XXIV first arose in Stockburger v. Riley, ${ }^{18}$ a proceeding to compel the State Controller to pay a claim for services performed under a one-year contract to waslı windows for a state agency. The Controller contended that a contract to perform sucl services outside of civil service was illegal and that payment under it would therefore be unconstitutional. The district court of appeal agreed and held that window washing was within the purview of the state civil service. The court rejected the argument that since the cost of window washing would be greater if done under civil service the agency should be

8 Id. $\S 2$ (c). The executive officer is to perform all of the duties of the Board except the adoption of rules, creation of classifications, dismissals and other punitive actions, which remain the duty of the Board as a whole.

8 Cat. Const. art. XXIV, \& 2 (a).

10 E.g., Cal. Stat. 1913, c.590.

11 Cad. Govt. Code \$\$ 18500-9763 (the Civil Service Act). Broadly, the Board is to administer and enforce all the powers of the state civil service. Nelson v. Dean, $27 \mathrm{Cal} .2 \mathrm{~d} 873$, 168 P.2d 16 (1946).

12 Emphasis added. Section 4(c) provides that all new jobs are similarly covered by civil service.

13 CaI. ConsT. art. XXIV, \& 4(a). Section 4(b) provides that the Legislature may remove the exemptions except for elective state officers, officers appointed by the Governor, employees of the University of Cahifornia, and menubers of the militia.

14 It does, however, seem probable that tenuporary appointments, as provided for in 86 , are not included in the language "every officer and employee."

15 State Compensation Ins. Fund v. Riley, 9 Cal. 2d 126, 69 P.2d 985 (1937); Burum v. State Compensation Ins. Fund, 30 Cal. 2d 575, 184 P.2d 505 (1947).

16 Ibid.

17 Burum v. State Compensation Ins. Fund, 30 Cal. 2d 575, 184 P.2d 505 (1947); State Compensation Ins. Fund v. Riley, 9 Cal. 2d 126, 69 P.2d 985 (1937); Stockburger v. Riley, 21 Cal. App. 2d 165, 68 P.2d 741 (1937); 17 Ops. Car. AtT'Y Ger. 152 (1951); 11 Ops. CaI. ArT'y Gen. 214 (1948). But see text at notes 25 and 26 infra.

1821 Cal. App. 2d 165, 68 P.2d 741 (1937). 
allowed to do it by contract. Such economic factors were held at best evidential and not enough in themselves to justify inroads in the civil service system. ${ }^{10}$

A dictum, however, stated that the exceptions listed im section 4(a) were not exclusive and that work that was intermittent, highly technical, special, confidential, temporary, or some combination of these qualities could be done outside of civil service by contract. ${ }^{20}$ Services not infused with these characteristics must be performed inside the scope of civil service.

The California Supreine Court was faced with a similar situation in State Compensation Ins. Fund v. Riley, ${ }^{21}$ also a proceeding against the Controller. The plaintiff, an attorney, had been retained by the Fund to protect its interest in pending federal tax litigation. The court held that payment slould be denied since the services could, and therefore should, have been performed by a civil servant. Apparently the duties involved could have been handled by the average attorney. By dictum again the court recognized that a state agency could enter into contracts with independent contractors under special circumstances but felt that the plaintiff's allegations failed to bring him under those circumstances. ${ }^{22}$ The tests adopted were those of the court in the Stockburger case as to whether the services could be done by contract rather than under civil service. ${ }^{23}$

In Burum v. State Compensation Ins. Fund ${ }^{24}$ the allegation was made that the services were of such a nature that they could not be done under civil service, and recovery was granted. The case presents a strikingly similar factual situation to that in State Compensation Ins. Fund v. Riley although in Burum the plaintiffattorney had been retained to represent the Fund in a specific suit in which a recovery was sought. The supreme court quoted approvingly the language of State Compensation Ins. Fund v. Riley but distinguished it factually in order to arrive at the opposite result. Thus there is an indication that if the services are such as would justify the hiring of permanent employees, the agency must resort to civil service if competent people can be obtained thereby.

It should be noted that not all people hired by state agencies, however, are considered employees of the state within article XXIV and, therefore, subject to civil service requirements. Assistants of the Building and Loan Commissioner, when their work relates only to one association taken over by the Commissioner and when they are paid out of the funds of such associations, are not employees of the state; ${ }^{25}$ nor are tax consultants hired by the Public Administrator to prepare tax returns for certain estates, when they are paid from the funds of these estates. ${ }^{28}$

10 This result seems clearly correct for even if it could be shown that in any one instance an independent contractor could do a job for less than it would cost the state to do the same job, the state may be able to cut its costs and amortize its initial outlay if it performed that type of service steadily.

2021 Cal. App. 2d 165, 170, 68 P.2d at 744.

219 Cal. 2d 126, 69 P.2d 985 (1937).

22 Id. at 135,69 P.2d at 989.

23 The court said that the test was "whether the services contracted for ... are of such a nature that they could be performed by one selected under the provisions of civil service. If the services could be so performed then in our opinion it is mandatory upon [the] appointing power [person or group having authority to appoint to positions in the state civil service, $C_{A x}$. Govr. CODE $\$ 18524$ ] to proceed in accordance with the provisions of the Constitution ...." 9 Cal. 2d at 134-35, 69 P.2d at 989.

2430 Cal. 2d 575, 184 P.2d 505 (1947).

25 Evans v. Superior Court, 14 Cal. 2d 563, 96 P.2d 107 (1939).

20 Estate of McMillin, 46 Cal. 2d 121, 292 P.2d 881 (1956). 


\section{Administration of Civil Service and the Authority to Contract}

An analysis of this problem is not complete without some examination of the procedure in the civil service system relating to contracting outside the civil service. Generally, the agency desiring to hire a person or firm by contract first draws up the contract and submits it with a statement of the nature of the work to be done to the State Personnel Board.27 This statement also specifies that existing civil service personnel are not equipped to do the job and requests that a contract for the services be allowed. This request is necessary in order to get the approval of the contract by the Personnel Board. ${ }^{28}$ Without such approval the Controller may refuse to draw a warrant to pay the contractor. ${ }^{29}$

At some point, usually before the contract is sent to the Personnel Board, the opinion of the Attorney General may be requested as to the legality of the proposed contract under article XXIV. His opinions show a close reliance on the case law. Thus, a contract for chief engineer for the San Francisco-Oakland Bay Bridge was approved on the grounds that the services were "highly technical, temporary, urgent, and not readily obtainable" through civil service. ${ }^{30}$ Similarly, the San Francisco World Trade Center Authority could contract for the completion of engineering and architectural plans as the proposed services were of "such magnitude, so urgent, special and technical" that they could not be performed by persons selected under civil service. ${ }^{31}$ Sales and promotional work and the preparation and finishing of brochures, advertising, and printing could be contracted out for the same reasons. ${ }^{32}$ Contracts for the dehvery of hunting and fishing licenses to retailers are valid because the work is intermittent and seasonal and, therefore, not considered amenable to competent performance by civil service personnel. ${ }^{83}$ On the other hand, private accounting firms may not be employed by the state to conduct an audit of state accounts in the absence of showing that the work is so technical that it could not be done by civil service employees. ${ }^{34}$ A contract for the delivery of parcel post from various state offices to the Sacramento post office would be invalid as the work was continuous and performed by civil service employees in other departments as well as being permanent and unspecialized. ${ }^{35}$

27 CaI. Govr. Code \$ 19052 states: "Whenever a vacancy in any position is to be filled and not by transfer, demotion, or reinstatement, the appointing power shall submit to the board, in accordance with board rules, a statement of the duties of the position, the necessary and desired qualifications of the person to be appointed, and a request that the names of the persons eligible for appointment to the position be certified." If, therefore, a list exists for the job, the matter is settled.

28 "The State agency has the responsibility for developing and presenting to the Personnel Board the facts warranting consideration of the agreement with the independent contractor. The Personnel Board then determines whether or not the services can be performed by persons employed under civil service procedures." Memorandum from the State Personnel Board, reprinted by California State Employees Association, March 15, 1956.

${ }^{29}$ CAL. Govr. Code \$ 12440 states: "The Controller shall draw warrants on the Treasurer for the payment of money directed by law to be paid out of the treasury; but a warrant shall not to be drawn unless authorized by law, and unless . . . specific appropriations . . . are available to meet it." (Emphasis added.)

30 Ops. CAL. ATT'y GeN. 10292 (1935).

312 Ops. CaL. Atr'y Gen. 79 (1943).

$32 \mathrm{Ibid}$. Are these services really such as do not lend themselves to competent performanco by civil servants?

3324 OrS. CAL. ATr'y GEN. 173 (1954). What is there about the delivery of fishing licenses to justify this opimion?

3417 Ops. Car. Att'y Gen. 152 (1951).

3524 Ops. Cal. Atr'y Gen. 173 (1954). 
The standards adopted by the Personnel Board when a contract is submitted for its approval are taken almost verbatim from the leading cases and from the opinions of the Attorney General. These standards are as follows: ${ }^{36}$

1. The services are so urgent, temporary, special and highly technical that the work could not properly be performed by resorting to civil service procedures. 2. The services are of such a unique or peculiar character that they could not be secured through civil service procedures.

3. The service depends in part on the use of materials not possessed by the the State agency at the time and place required and the cost to the State in procuring such equipment would be disproportionate for the result obtained. 4. The work, in addition to being of a special or technical character, is likewise intermittent or irregular although extending over a considerable period of time. 5. The work to be performed is of a character that it is impossible to have performed by civil service employees. Examples would be independent appraisals of property to be purchased by thie State or certain highly confidential investigations.

6. The amount of work to be performed is such that sufficient persons cannot be obtained through civil service procedures to do the work.

7. The above bist is not exhaustive, but most cases will be found to fall within these catagories or some combination of them.

It seems, therefore, safe to assert that the civil service provision of the California constitution does not prohibit contracting for services with independent contractors in varied situations as that provision is interpreted by the Personnel Board. Furthermore, the quoted excerpt does not seem to be the complete picture of the practice of the Personnel Board. An examination of the many contracts approved yearly would probably reveal that a de minimus rule is actually used in examining agency requests for approval of contracts for services and that the above discussed rules are followed only on larger and more important contracts. In a state such as California, with a large volume of public works projects and a usual urgency for completion, this program may be necessary and desirable so long as the public interest in a strong civil service is protected by the Personnel Board's limiting this practice to relatively unimportant contracts.

\section{The State Contract Act: A Collateral Issue}

In the light of the foregoing discussion it appears that the State Contract Act ${ }^{37}$ is in contravention of article XXIV of the California constitution. The act requires most state highways and buildings to be constructed by private contractors ${ }^{38}$ and regulates the taking of bids, ${ }^{39}$ selecting of recipients of awards, ${ }^{40}$ and similar matters. It seems clear that the State of California engages in enough construction of roads, buildings, and other projects subject to the act to justify establishing einployment procedures for such projects and for the State to do the construction

86 Memorandum from the State Personnel Board, reprinted by California State Employees Association, March 15, 1956.

87 CAL. Govt. CODE $\$ \S 14250-424$.

$38 \mathrm{CAI}$. GovT. CODE $\$ 14254$ provides for the following projects to be carried out under this title: erection, construction, alteration, repair or improvement of any state structure, building, road or other state improvement of any kind costing more than $\$ 2,000$.

89 CaI. Govt. CODE $\$ \S 14310-16$.

40 Cat. Govt. Code $\$ \S 14330-35$. 
itself. The amount of specialization and skill in personnel and equipment is not so great that the State could not readily obtain it in most instances. ${ }^{41}$ It is here submitted that this program could be administered by the Personnel Board in the same manner that other state positions are handled. It is a hittle surprising that this question has never arisen, ${ }^{42}$ at least publicly, since so much money is spent each year on this type of contract. The reason may well be related to the very magnitude of the sums involved and the political power of the recipients. The subject, however, slould be examined on its merits in the light of the evident constitutional objections to the present practice. Either the act should be changed to conform to the mandates of the constitution or the constitution should be amended to accommodate the State Contract Act, whichever appears to be in the best interests of the citizens of California.

\section{Conclusions}

Given the California constitutional civil service system, the law relating to the authority to contract with the state for services outside civil service may be placed on three levels: judicial, administrative theory, and administrative practice. Under the Stockburger, Riley, and Burum cases the autlority exists only when the circumstances are such that the services would be special, highly technical, intermittent, and could not be performed by personnel selected under civil service. Administrative theory has adopted these mandates but in applying them has made some rather unusual applications. On the level of administrative practice, there may be a laxity im enforcing these rules in situations where the services are minor. This examination reveals that state agencies have adequate power to contract with independent contractors when it is clear that in the long run the interests of state efficiency and responsibility are protected.

Malcolm S. Burnstein*

\footnotetext{
41 Indeed, the State now does road and building maintenance for which it owns equipment and employs trained civil service personnel.

42 It is doubtful whether anyone would raise the issue and in the event of a taxpayer's suit, the court would probably find that the complainant had no standing to sue. Cf. Davis, Standing to Challenge Governmental Action, 39 MnN. L. REy. 353 (1955).
}

* Member, Second-Year Class. 